\section{Violence among youth in Jamaica: a growing public health risk and challenge}

\author{
Delores E. Smith ${ }^{1}$ \\ and Katherine E. Green ${ }^{2}$
}

Although the overwhelming majority of Jamaican children and adolescents are well adjusted, a substantial group exhibits high levels of maladjustment and deficient functioning (1). A perfunctory review of Jamaican newspapers and television talk-shows reveals that violence, particularly violence perpetrated by youths, is of major concern in every sector of Jamaican society. Although aggressive and violent behaviors are not new in Jamaica, the recent escalation of criminal violence among the adolescent population has become a major public policy issue and a serious public health problem. Violent activities have become more vicious and the perpetrators more ruthless than what the typical Jamaican over 40 years of age is used to (M. Jones, Social Scientist, personal communication, 8 March 2006).

The purpose of this article is to review the relevant literature, describe the existing knowledge regarding aggression and violence among children and youth in the Jamaican context, and evaluate the plausibility of popular assumptions regarding the correlates of aggressive and violent outcomes in Jamaican children and youth. This article assesses the relationship between ecological processes and youth outcomes in Jamaica and is organized in the following manner: the first section addresses the incidence of violence and its impact on society; the next section focuses on the overall conceptual framework and its usefulness in assessing child outcomes in the Jamaican context. Pursuant to that, the individual attributes of violent outcomes are addressed, as well as two levels of the ecological environment: the proximal (near) environment and the distal (far) environment. In the proximal context, the issue of parental involvement is addressed as two separate issues: father absence and mother absence. This is because a substantial number of Jamaican children, historically, have not had "involved" fathers, and recently, the issue of mother absence has featured prominently in the discussions surrounding youth problem behaviors in Jamaica. The final section summarizes the article and discusses implications for policy decision making.

\section{STATE OF VIOLENCE IN JAMAICA}

In 2000, Jamaica ranked third in the world in murders per capita (2). By the end of 2005, police crime data indicated a record number of annual homicides (63.0 per 100000 inhabitants), a rate 
greater than three times the global average of 19.4 per 100000 (2). These statistics are in addition to the high rates of rape, stab wounds and other injuries, and assaults $(2,3)$. Consistent with global trends, young males from 15-29 years of age are disproportionately represented, both as victims and perpetrators of violence. In 2002, this demographic group was responsible for $80 \%$ of the violent crimes, $75 \%$ of the murders, and $98 \%$ of all major crimes committed in Jamaica (3,4). Also in 2002, $55 \%$ of those arrested were males under 25 years of age. Among the new admissions to correctional institutions in 2002, 32\% were under 25 years of age and $83 \%$ were males (4). From $68 \%-76 \%$ of homicides involved the use of firearms (5).

Violence is the leading cause of death in young Jamaican males and the fifth leading cause of death for people of all ages (3). An increasing number of women and children are also victims of violent criminal activity. Police records for 2003 indicate that females were the victims of the 1308 reported cases of rape and 9\% of the murders (6). In 2004, 119 children were murdered and 430 suffered gunshot wounds. In the same year, children represented $70 \%$ of the victims of sexual crimes; males $16-25$ years of age were arrested for $47 \%$ of the rape cases $(5,6)$.

The focus here is on violence perpetrated by youth because Jamaica, a small island democracy of 4411 square miles within the Region of the Americas, has one of the highest youth-perpetrated violence rates in the world $(2,5)$. However, research on social processes and child outcomes in the Region, particularly in Jamaica, is sparse. Consequently, little is known about the relationship between local ecological processes and the high incidence of aggression and violence among Jamaican children and youth. Nevertheless, there have been various conjectures about the root causes of youth dysfunctional outcomes. While many of these speculations, most originating from the local media, have been targeted at the socialization practices of Jamaican parents, much less blame has been directed at related macro-level factors, such as urbanization and its attending problems. However, a large body of international research has demonstrated that violence is a complex and multifaceted phenomenon. Therefore, no single factor can explain its etiology or existence $(5,7)$.

\section{Impact of violence on Jamaican society}

The devastating impact of widespread violence on social order has been widely documented. As is the case worldwide, all types of violence pose serious public health risks and exact both direct and indirect costs on society $(3,7,8)$. The impact in terms of death, injuries, short- and long-term disabilities, and mental anguish is vast (7). In addition, violence impedes social advancement and deters economic growth and development. Violence inhibits the recruitment and retention of a highly skilled workforce and forces society to expend a disproportionate amount of its national budget on violence-related health care, security, and crime fighting (3). Jamaica is no exception, spending an extraordinarily high percentage of its gross domestic product on violence-related issues and struggling with reduced human capital, productivity, and quality of life $(2,7,8)$. Moreover, the high cost of doing business makes the society unable to compete in the global economy $(2,3)$. According to Brown (9) ". . investments from both local and foreign sources, which could create new employment, are being shelved; the educational system is being affected; social interactions are being disrupted; and, the citizens are gripped in fear, unable to live normal lives which prevail in other civil societies." In monetary terms, violence costs the country an estimated J\$ 15 billion in health care, lost economic activities, and human suffering; violence related injuries cost the economy more than $\mathrm{J} \$ 700$ million per year (3). It is worthy of note that, consistent with global trends, the costs of violence are unevenly distributed since violent crimes are concentrated among the lowest economic segment of society $(3,5,7)$.

\section{CONCEPTUAL FRAMEWORK}

Ecological systems theory has been identified as one of the preeminent perspectives in assessing and understanding human development and behavior $(2,7)$. The framework emphasizes how inseparable the individual and the social environment are, and underscores the saliency of their interactions in effecting developmental outcomes (10). The perspective implies that to understand an individual's development, the interrelationships of the multiple processes and contexts within which that individual develops must be understood. The framework assumes that developmental outcomes emanate from a complex web of exchanges between the individual and the culture. These exchanges take place within a system of proximal and distal contexts to either promote or stifle development; therefore, all systems work together to influence what the individual becomes.

Proximal processes consist of the direct interactions between the individual and the immediate environment. Distal processes, on the other hand, are those interactions that occur outside of the im- 
mediate environment, but nevertheless affect the individual through consequences on the proximal processes. Consistent with the theory, it is argued here that violent tendencies in some Jamaican adolescents develop from the interactions of distinct social forces and youth characteristics, often via feedback from the environment to the child.

\section{INDIVIDUAL CHARACTERISTICS}

Personal characteristics such as low selfesteem, poor social problem-solving skills, and low empathy $(11,12)$ have been identified as robust predictors of violent tendencies in children and youth. In one study (11), inhibition, negative selfrepresentation, and low sense-of-self predicted the development of aggression and overall maladjustment in children. Maladjusted youth show a propensity to exhibit increased resistance to social integration and gravitate toward dysfunctional peer activities such as gangs $(13,14)$. Those activities fill the youth's need for identity, sense of belonging, and worthiness (14). One study, employing causal modeling techniques, concluded that youth who suffered from deficient self-esteem tended to restore their self-esteem by engaging in delinquent activities (14). In Jamaica, the prevailing contention is that many Jamaican children and youth suffer from chronic feelings of unworthiness and lack hope for the future, a belief espoused by a prominent leader who noted that Jamaican youth "... do not have any inspiration or motivation to plan positively for the future. The decline in values and attitudes among some of our youth can be traced to the fact that they too have given up and don't have the drive to go on" (15).

Biology is another factor that has been implicated in violent tendencies, but the relationship is unclear. However, there is strong scientific evidence suggesting that many adverse biological outcomes may be a result of deficient social environments. For example, harsh prenatal and postnatal environments may be responsible for poor brain development and function. Studies have shown damage to or deficiency in the prefrontal cortex of the brain of criminally violent individuals (16). Studies have also shown that children who had "received damage to their prefrontal cortex before age 7 , developed abnormal social behavior, characterized by an inability to control frustration, anger, and aggression" (16). Furthermore, fetal exposure to tobacco, alcohol, drugs, and/or lead during and after pregnancy can result in stunted nerve and brain cells in the child, causing neurological problems; postnatal exposure to those same toxins have similar consequences (17). Maternal depression can impede the maternal response and stimulation needed for optimal emotional functioning, while inadequate pre- and postnatal nutrition can stunt growth in all aspects of development (17).

In Jamaica, exposure to toxins is high among children. Studies have reported evidence of severe lead toxicity in Jamaican children, which is often manifested as seizures or other neurological problems (18). Also, despite improvement in the nutritional status of Jamaican children over the last decade, it continues to lag behind international standards (19). As indicated in the sections that follow, many Jamaican families experience other harsh social environments that have been shown to adversely affect biological processes and can lead to developmental and behavioral problems.

\section{PROXIMAL ENVIRONMENT}

\section{Childrearing}

Research has shown that parental nurturance and responsiveness facilitate favorable child outcomes. Conversely, punitive and neglectful parenting put children at risk for undesirable consequences $(20,21)$. Also, the academic literature has suggested that harsh parenting is a serious risk factor for children's aggressive and violent behaviors; hostile and abusive families produce violent children and youth (21-23). Both cross-sectional and retrospective studies have shown a positive relationship between physical punishment and aggressive behavior $(22,23)$. One study found this relationship to be particularly robust for boys who lacked close identification with their fathers (22).

The literature has purported that the discipline typically practiced by Jamaican parents and caregivers teaches children to be violent $(24,25)$. Flogging, a culturally sanctioned form of punishment, is the primary disciplinary practice utilized by the majority of parents and caregivers, while spanking (as opposed to flogging) is practiced by only 3\% (25). Adults "hitting [children] with a belt and sticks is omnipresent. There is also pushing, with children being flung bodily into furniture ... [and] boxing, hitting, kicking and chopping children" (4). These are common responses to perceived misbehavior. "Children are regularly smacked, flogged, and even threatened with weapons" (26). In 1998, 80\% of children in childcare facilities in Jamaica reported experiencing abusive incidents at the hands of caregivers (24). A study by the Jamaican Ministry of Health, found that $84 \%$ of children reported being beaten with an object at home while another $8 \%$ reported being kicked, bitten, or beaten up (4). In 2002, 2183 children were 
treated in emergency rooms across the island for injuries inflicted by parents and caregivers; $70 \%$ of those cases involved the use of sharp or blunt instruments and $18 \%$ involved the use of bodily force (4). Undoubtedly, the pervasive use of harsh physical punishment in the home (and society) has legitimized the use of violence against children $(1,24$, $25)$. It may be instructive to know that in a Jamaican study, $66 \%$ of boys and $50 \%$ of girls in the Jamaican sample rated as "highly aggressive" were from homes where physical punishment was the primary disciplinary measure (27). Scholars have contended that if society employed strategies to reduce abusive, hostile parenting, the incidence of societal violence would decrease significantly $(21,23)$.

\section{Parental involvement}

"Parental involvement in their children's lives is one of the most important-if not the single most important-contributor to children's healthy psychological development" (21). Therefore, parents who are detached physically and/or emotionally put their children at risk for serious negative developmental outcomes $(22,28)$. Studies have shown that, in comparison to their peers with involved parents, adolescents with disengaged parents are significantly more likely to exhibit psychiatric difficulties, school failure, and serious misconduct (e.g., delinquency, alcohol and drug use, violence, and sexual precocity) (21).

Father absence. A father in the home, independent of mother's contribution, serves a protective function against maladaptive outcomes (29). In the United States, empirical studies have indicated that children from homes where there is no father present experience significantly more physical, cognitive, psychiatric, and behavioral problems than their peers residing in homes with a father present (30). For example, a child with a nonresidential father is five times more likely to live in poverty; two times more likely to suffer physical, educational, and emotional neglect; at $120 \%$ greater risk to suffer some type of abuse; and has significantly higher odds of incarceration than their peers with a father present in the home (31). Children from fatherabsent homes often harbor feelings of hostility and rejection, have a high occurrence of association with deviant peers, and involvement in negative peer activities (32). Conversely, the academic literature has explicated the positive consequences for overall family well-being when the child's father is present and involved in his or her life (30-32). In the United States, $85 \%$ of prison inmates had no father at home (33).
In Jamaica, a high rate of father-absence has been the norm historically. However, in present day Jamaica, family dispersal and the diminution of the extended kin leave many children without the traditional compensatory network (29). The noticeable increase in the number of street children, especially in urban Jamaica, and the concomitant rise in the incidence and severity of problem and criminal behaviors among youth, have stirred renewed interest in the effect of father-absence on the developmental outcomes of Jamaican children (29, 33-35). Some have posited that in Jamaica, the combination of father absence and female dominance is responsible for the low levels of responsibility and high aggression and hostility in Jamaican males (34). Also, Wright (35) delineated father absence and, by default, deficient parenting as the principal causes of youth problem behaviors. Crawford-Brown (28) examined the relevance and importance of the father in delinquent outcome in Jamaican adolescent boys and found that $77 \%$ of delinquent youth in the sample indicated the presence of negative role models in their lives; $70 \%$ implicated their fathers as that negative role model. Keddie (36) found that Jamaican girls without a father residing in the home were three times more likely to become pregnant than their father-present peers. Sharpe (37) maintained that the distress brought on by way of absent fathers and the accompanying family instability put Jamaican children at serious risk for physical injury, developmental delays, and psychopathological difficulties, issues, she contended, that are too crucial for society to ignore.

Mother-absence. Despite the "new" societal alarm regarding mother absence, the phenomenon is not new. A sizable Caribbean literature has documented the practice of mother-absence in the region (38). Traditionally, when mothers migrated from rural to urban areas of the country in search of economic opportunities, children were left in the care of close family members, such as grandparents and aunts. In present-day Jamaica, children are, in many cases, abandoned and left to fend for themselves when their mothers or parents emigrate overseas in search of a better standard of living for themselves and their families (39). In other instances, children are left with strangers or in the care of older siblings who are often themselves children, dynamics that put children at extremely high risk for physical and sexual abuse $(39,40)$. Like father absence, mother absence has been speculated to be a primary cause of youth social ills. In one study, $60 \%$ of delinquent teenagers at correctional institutions in Jamaica had mothers who had migrated abroad $(39,40)$. Crawford-Brown (28) examined the relationships between family variables and 
conduct disorder in a group of Jamaican adolescent boys and found mother-absence, low contact with mother, and instability in living arrangements to be the factors most related to adolescent conduct disorder. Specifically, $87 \%$ of the conduct-disordered group were boys from homes where the mother was absent during childhood, compared to only $13 \%$ for the comparison group. In addition, $81 \%$ of mothers of boys in the study group reported little contact with their children during childhood, compared to $19 \%$ of mothers in the comparison group. Furthermore, $92 \%$ of the conduct-disordered children had experienced two to six changes in parental living arrangements.

According to Campbell (39), the phenomenon of mother absence in Jamaica is both significant and disturbing because in the past mother had always "been there" to provide the physical and emotional comfort the developing child so desperately needs. Yet, increasing economic, social, and psychological demands on parents have deprived children of the security they need from adults. Feelings of insecurity and perceptions of neglect on the part of children can engender mental health problems and behavioral difficulties (21).

The context of school. School is another critical component of the child socialization process. School is the setting in which children spend most of their day outside of the family, and therefore, is a prime factor in children's adjustment and functioning. In addition, academic achievement is a salient aspect of children's self-worth, a strong deterrent to deviancy (21), and a robust indicator of social and economic potential (41). Therefore, the quality of the school experience is a key ingredient in identity development, morality, and interpersonal relationships $(41,42)$. School contexts that pupils perceive as harsh, oppressive, and threatening foster frustration, resentment, school failure, and hostility in pupils, factors that potentiate serious adverse life consequences $(41,42)$.

The quality and efficacy of the teachinglearning process in the Jamaican context has been deemed problematic. The extreme disciplinary measures meted out to children at home extend into the school where corporal punishment is utilized both as a disciplinary ritual and a pedagogical strategy $(24,25)$. In one study, $91 \%$ of the teacherrespondents reported using corporal punishment (43). In another study, $63 \%$ of the girls reported that they had been physically punished by their teachers (44), and in still another study, teachers defended "the necessity to use the strap" and cited the biblical dictum "not to spare the rod and spoil the child" (24). Ustanny (4) summarized local research and noted that corporal punishment was identified as the greatest risk factor for school aggression especially among boys; $80 \%$ of boys and $70 \%$ of girls reported a lifetime prevalence of being beaten with an object and $14 \%$ of boys and 1\% of girls indicated that they carried a weapon (most often a knife) to school all the time; students reporting academic difficulties were significantly more likely to fight with a weapon.

Day (42) hypothesized that the indiscipline, lack of social responsibility, and belligerency evidenced in Jamaican youth were directly linked to the harsh treatment, specifically corporal punishment, administered to children by teachers. He reasoned that such treatment created distress, anger, and rage in pupils. "Deeming themselves recipients of injustice, they [youth] sometimes proceed to wreak vengeance on the school and the community.... Violence begets violence and neither academic learning nor the acquisition of values can be enhanced by the application of force" (42). A summary of research published by the Jamaican Ministry of Health (4) linked the pattern of male involvement in crime to the societal practice of child battering.

\section{DISTAL CONTEXT}

\section{Poverty and income inequality}

Family economic status is a macro-level contextual factor that exerts a powerful effect on family functioning and child developmental outcomes. Compared to their more financially advantaged peers, children from low-income families tend to have more negative family, school, and societal consequences (45), partly because families experiencing poverty possess neither the material nor the psychological resources to protect their children from the pressures that accompany economic deprivation $(25,45)$. The strains of poverty may contribute to parental mental health problems, which in turn, elevate negative parenting; negative parenting increases the risk for conduct disorders in children $(45,46)$. For example, stressful social and economic conditions may create anger, frustration, and hostility in parents; parents in turn may displace their anger and frustration on their children to the point of abuse (25). Although, physical punishment is not confined to people in chronic poverty, research has consistently shown that such extreme discipline tends to be more frequent and severe among low-income groups; among more advantaged groups physical punishment might be used less regularly and tempered by other nonviolent means of discipline $(21,25)$. Steinberg (21) maintained that, "By far, the most insidious cause of negative parenting is poverty." 
Poverty increases families' vulnerability to crime and violence. Although violence is not confined to urban communities or the economically disadvantaged of society, violent crimes tend to be concentrated in urban inner-city neighborhoods where the residents are both the victims and perpetrators of violent crimes. Moreover, the urban poor tend to exhibit greater tolerance for and more positive attitudes toward deviancy and illicit activities (e.g., the drug trade), behaviors that are invariably tied to ruthless community violence $(7,47)$. Besides, economic hardship enhances youth susceptibility to gang membership and warfare and their attending problems, such as violent criminality and early violent death $(46,47)$. Gang membership increases the probability of alcohol consumption, illegal drug use, and the use of weapons in conflict resolution (8). Access to, distribution, and trafficking of drugs and firearms are associated with increased levels of violent crimes, especially murder $(3,47)$.

Undoubtedly, chronic poverty and escalating violence wield an exacting toll on a significant proportion of the Jamaican population, particularly those residing in the urban inner cities. Kingston, the capital city, accounts for $25 \%$ of the total population and over $70 \%$ of its violent crime (47). Families in the inner-cities neighborhoods invariably experience social isolation, chronic unemployment, high incidence of domestic and community violence, and involvement in illegal activities $(46,47)$. Because of their relative lack of physical, social, and economic power, youth from economically disadvantaged families experience higher rates of physical and sexual abuse and other forms of psychological abuse than their more advantaged counterparts (8), dynamics that are likely to exacerbate anger, fear, and despair in people in those contexts and lead to severe behavior problems $(8,45,47)$. Furthermore, poverty increases youth susceptibility to gang membership, gang warfare, and their attending problems, such as violent criminality and premature death $(3,47)$. A substantial body of empirical studies has demonstrated a robust link between poverty and various maladaptive outcomes in children and youth; these include elevated levels of delinquency and criminality $(21,46)$. So potent is the effect of poverty on youth outcomes that many social scientists assume that poverty alleviation would reduce antisocial behaviors, in general, and violence, in particular (21).

\section{CONCLUSIONS}

Although antisocial behavior among young people in Jamaica is not new, it has become more frequent and vicious than it was historically. Hence, behavior problems have changed both quantitatively and qualitatively and have a more devastating impact on society than they formerly did (47). However, youth outcomes do not occur or persist in a vacuum but result from the confounding effect of several personal and environmental factors. For example, inept parenting, problematic child socialization, and youth disengagement from school are social factors that have dire consequences for children, families, and society; when poverty is added, the detrimental sequelae are compounded.

If the human ecological reasoning is correct, it would appear that the social dynamics of Jamaican society have led some children to encounter a complex and potent mix of negative experiences that has put them at risk for compromised development. Arguably, chronic poverty severely inhibits many families' capacity to provide the basic necessities for their children and hinders caregivers' ability to engage in the desirable affective and nurturing behaviors that have been shown to effect optimal child development. Therefore, it is incumbent on society to make an investment of time, effort, and money to institute programs aimed at reducing poverty (21), and by extension, alleviating dysfunctional and maladaptive behaviors in youth.

Because children are the most vulnerable victims and witnesses of violence, strategies to protect them are imperative. Also, because the factors that jeopardize optimal child outcomes are embedded in the family, community, and society, workable approaches must be directed at all those levels. Furthermore, because of the interconnectedness of all three levels, a change at one level will improve outcomes for children and youth $(7,24)$. Multipronged programs have shown great promise as both a prevention strategy and an intervention in reducing the likelihood of more costly interventions later on (48). Those programs typically address the problematic dynamics of the whole family. They provide services to teach good parenting skills, marital and family counselling, and quality childcare programs. Good quality programs help create healthy family relationships, keep children and youth in school, and thwart behavioral problems (48). The High/Scope Perry Preschool Project in the United States has demonstrated that every dollar invested on high quality preschool programs saved society US\$ 16 in taxes, with an overall economic return to the public of US\$ 244812 per participant. The program included a parent involvement component where teachers visited the child's home each week and spent 1.5 hours with each mother and child to involve the mother in the educational process and help implement the preschool curriculum at home. At age 40, adults who had attended the high quality preschool program were $42 \%$ less 
likely to be incarcerated and had a $36 \%$ lower arrest rate for violent crimes (49).

Numerous observers have called for sweeping reforms of the entire Jamaican educational system. Their various proposals are typified by Espuet's (42) contention that to "save" Jamaican youth, the chronic illness of the education system must be addressed and "no less than a complete revamping of Jamaica's education system is now required." For example, teacher preparation programs must focus on the relevant theoretical and empirical information regarding best practices for contemporary students (25). The United Nations (24) has suggested, among other things, the intensification of the teacher training programs and institution of a comprehensive school guidance program. Prevatt and Kelly (50) contended that the most successful academic programs were those that were responsive to youth's academic, emotional, and social challenges. Effective programs provided a caring and non-threatening environment where students felt nurtured and industrious. Those programs engaged in developing strong parent-school partnerships and fostered good interpersonal relationships (i.e., teacher-parent, teacher-student, and student-student). They also provided academic remediation and teacher and parenting training in child behavior management, and social skills for students $(50,51)$. Other effective societal strategies include reducing youth access to firearms, punishing violence and rewarding non-violence (8), and reorganizing the juvenile justice system to provide adequate space for juveniles who have been apprehended, rather than placing them in jails as is commonly done now (24).

In sum, the academic literature suggests that oppressive environments are closely linked to hostility and violence. Therefore, policymakers must focus on both prevention and intervention strategies to reduce children's exposure to violence and youth involvement in violence. To prevent and reduce violence in ensuing generations, it is obligatory that risk factors at all levels of the ecological system be addressed, preferably simultaneously.

\section{SINOPSIS}

\section{La violencia en jóvenes de Jamaica: un creciente riesgo y reto de salud pública}

En Jamaica, la abrumadora mayoría de los jóvenes son personas bien ajustadas social y emocionalmente. Sin embargo, el aumento vertiginoso de las agresiones y la violencia en la niñez, y la conducta delincuencial entre los jóvenes se han convertido en una gran preocupación para la sociedad y constituyen un grave problema de salud pública. A falta de investigaciones definitivas sobre las causas, las especulaciones apuntan a la frustración, los sentimientos de inadaptabilidad y la falta de autonomía de los jóvenes. El propósito de este artículo es revisar la literatura y describir la información existente relacionada con la violencia en Jamaica y evaluar la plausibilidad de las suposiciones de la población acerca de los factores relacionados con este problema. Según la literatura analizada, hay una convergencia de factores a niveles micro y macro que influyen fuertemente en el comportamiento de los niños y los jóvenes jamaicanos. En este trabajo, estos factores se operacionalizan en tres niveles: el individual, el contexto social proximal (la familia y la escuela) y el contexto social distal (i.e., las circunstancias económicas). A partir de la literatura, se concluye que el comportamiento violento de algunos jóvenes jamaicanos puede tener sus raices en la confluencia de los problemas que abruman a las familias, los niños y los jóvenes. La exposición de los niños a la violencia, tanto en el seno familiar como en la escuela, es particularmente preocupante. Se discuten las implicaciones para las decisiones en politicas.

Palabras clave: violencia, conducta del adolescente, Jamaica.

\section{REFERENCES}

1. Williams L. Anywhere yuh be, yu not safe: Adolescence and violence in Jamaica. Available from: http://www. unicef.org/evaldatabase/files/JAM 2001_803.pdf. Accessed on 20 March 2006.

2. World Bank. Crime, violence, and development: trends, costs, and policy options in the Caribbean. A joint report by the United Nations Office on Drugs and Crime and the Latin America and the Caribbean Region of the World Bank. Washington: DC; 2007. (Report no. 37820).
3. World Bank. Jamaica: The road to sustained growth. Washington, DC; 2003. (Report no. 26088-JM).

4. Ustanny A. Battered boys-Research links harsh punishment to crime levels. Available from: http://www.jamaicagleaner.com/gleaner/20040111/lead/ lead1.html. Accessed 31 March 2004.

5. UNICEF. Situation analysis of Jamaican children, 2005. Available from: http:// www.unicef.org/jamaica/situation analysis.pdf. Accessed 5 February 2006.

6. Bailey B. Gender profile: Jamaica. Center for Gender and Development Studies.
University of the West Indies, Mona, Jamaica; 2005.

7. World Health Organization. World report on violence and health. Geneva: WHO; 2002.

8. Weaver K, Maddaleno M. Youth violence in Latin America: current situation and violence prevention strategies. Rev Panam Salud Publica. 1999;5(4/5): 338-43. Available from: http://www. scielosp.org/pdf/rpsp/v5n4-5/ v5n4tm4.pdf. Accessed 15 October 2007.

9. Brown P. P. J. Patterson's collapsing legacy. Available from: http://www. 
jamaica-gleaner.com / gleaner / 20050731/lead/lead5.html. Accessed 31 July 2005.

10. Bronfenbrenner U, Ceci, SJ. Naturenurture reconceptualized in development perspective: A bioecological model. Psychol. Rev., 101(4):568-86.

11. Watson M, Fischer K. Pathways to aggression through inhibited temperament and parental violence. Available from; http://www.gse.harvard.edu/ news/features/fischersummary.html. Accessed 16 March 2006.

12. Cowen EL, Work WC, Wyman PA, Parker GR, Wannon M, Gribble P. Test comparisons among stress-affected, stress-resilient, and nonclassified fourth through sixth-grade children. J Community Psychol.1992; 20(4):200-14

13. Elliot GC, Cunningham SM, Linder $M$, Colangelo M, Gross M. Child physical abuse and self-perceived social isolation among adolescents. J Interpers Violence. 2005; 20(12):1663-84.

14. Reasoner RW. Review of self-esteem research. Available from: http://www. self-esteem-nase.org/research.shtml. Accessed 20 March 2006.

15. JIS. Young Men Need Greater Self Worth Says PM Thursday. Available from http://www.jis.gov.jm/officepm/html/ 20060824t130000-0500_9817_jis_young men_need_greater_self_worth_says_pm. asp. Accessed 20 October 2007.

16. Society for Neuroscience. Violent brains. Available from:http://apu.sfn.org/ index.cfm? pagename $=$ brainBriefings violent brains. Accessed 12 August 2006.

17. National Center for Children in Poverty. Poverty and Brain Development in Early Childhood. Available from: http:// www.nccp.org/pub_pbd99.html Accessed 19 August 2006.

18. Evans-Gilbert, W. Lead poisoning in Jamaican children. Available from http:/ / www.jamaica-gleaner.com/gleaner/ 20040414/news/news5.html. Accessed 3 September 2004.

19. PIOJ-Planning Institute of Jamaica and Statistical Institute. Eradicating extreme hunger and poverty: A review of the Jamaican situation. Available from: http: / / www.pioj.gov.jm/piojdocs / special/Beginnings/. Accessed 4 March 2006.

20. Gershoff ET. Corporal punishment by parents and associated child behaviors and experiences: A meta-analytic and theoretical review. Psychol Bull.2002; 128(4):539-79.

21. Steinberg L. Youth violence: Do parents and families make a difference? National Institute of Justice Journal, April 2000. Available from: http:/ / www.ncjrs. gov/pdffiles1/jr000243f.pdf. Accessed 23 March 2006
22. Lefkowitz M, Eron L, Walder L, Huesmann L. Growing up to be violent: A longitudinal study of the development of aggression. New York: Pergamon; 1999.

23. Straus MA, Yodanis CL. (1996). Corporal punishment in adolescence and physical assaults on spouses in later life: what accounts for the link? J Marriage Fam. 1999; 58(4):825-41.

24. United Nations. Convention on the rights of the Child-Jamaica, 1999. Available from; http://www.crin.org/docs/ resources/treaties/crc.33/Jamaica_ngo_ report.pdf. Accessed 30 March 2006.

25. Smith DE, Mosby G. Jamaican childrearing practices: The role of corporal punishment. Adolescence. 2003;38(150): 370-81.

26. World Bank. A review of gender issues in the Dominican Republic, Haiti, and Jamaica. Washington: DC: World Bank; 2002. (Report No. 21866-LAC)

27. Headley B. The false promise of flogging. The Sunday Gleaner 1994. August 14:A23 (col. 2).

28. Crawford-Brown $\mathrm{C}$. The impact of parenting on conduct disorder in Jamaican male adolescents. Adolescence. 1999. 34(134):417-36

29. Leo-Rhynie EA. Class, race, and gender issues in child rearing in the Caribbean. In: Jaipaul L, Rooparine J, Brown, J, eds. Caribbean Families: diversity among ethnic groups. Greenwich, CT: Ablex; 1997. Pp. 25-56.

30. Robin MW, Spires RC. The consequences of father absence: A crosscultural perspective. In: Adler, LL, ed. Cross-cultural research in human development. New York: Praeger; 1989. Pp. 47-57.

31. National Fatherhood Initiative. The father factor. Available from https:// www.fatherhood.org/father_factor.asp. Accessed 14 October 2007.

32. Fagan PF, Rector R. The effects of divorce on America. Washington, DC: The Heritage Foundation; 2000.

33. Luton, D.Absent fathers force societal breakdown. Available from: http:// www.jamaica-gleaner.com/gleaner/ 20070923/news/news1.html. Accessed 17 October 2007.

34. Hamilton M. A review of educational research in Jamaica. In: Miller E, ed. Education and society in the Commonwealth Caribbean. Jamaica: Institute of Social and Economic Research; 1991. Pp. 105-42.

35. Wright K. Dads blamed for delinquent youths. The Sunday Gleaner 2000. October 1: C11(col 1).

36. Keddie AM. Psychosocial factors associated with teenage pregnancy in Jamaica. Adolescence.1992;27(108): 873-90.
37. Sharpe J. Mental health issues and family socialization in the Caribbean. In: Rooparine JL, Brown J, eds. Caribbean families: Diversity among ethnic groups. Greenwich: Ablex; 1997. Pp. 259-270.

38. Barrow C. Family in the Caribbean: Themes and perspectives. Jamaica: Ian Randle;1996.

39. Campbell J. Horrors of the barrel kids. The Sunday Gleaner 1995. October 29: A1 (col.1).

40. Larmer, B. The barrel children. Newsweek 1996:127(8) 45.

41. Espeut P. School reform. Available from http://www.jamaica-gleaner.com/ gleaner/20040107/cleisure/cleisure4. html. Accessed 10 February 2004

42. Day G. The only permanent solution to crime. The Sunday Gleaner 1994. October 2: B7 (col.1).

43. Browne R. Parental neglect: A factor causing indiscipline. The Sunday Gleaner 1994. May 1: A3 (col.1).

44. Walker SP, Grantham-McGregor SM Himes JH, Williams S, Duff EM. School performance in adolescent Jamaican girls: associations with health, social and behavioral characteristics, and risk factors for dropout. J Adolesc. 1998. 21(1) 109-122.

45. Evans GW. The environment of childhood poverty. Am Psychol. 2004;59(2): 77-92.

46. Ary DV, Duncan TE, Biglan A, Metzler CW, Noell JW, Smolkowski K. Development of adolescent problem behavior. J Abnorm Child Psychol. 1999;25(2): 141-50.

47. Harriot A. Crime trends in the Caribbean. Report to the United Nations Office on Drugs and Crime. University of the West Indies, Jamaica, 2002.

48. DeBord K. Communicating program value of family life and parenting education programs to decision makers. J Extension. 2005; 43 (2). Article Number 2IAW2. Available from: http://www. joe.org/joe/2005april/iw2.shtml. Accessed 14 October 2007.

49. Schweinhart LJ. The High/Scope Perry Preschool study through Age 40: summary, conclusions, and frequently asked questions. Available from: http:// www.highscope.org/file/Research/ PerryProject/3specialsummary \%20co1 $\% 2006 \% 2007$.pdf. Accessed 15 October 2007.

50. Prevatt F, Kelly F. Dropping out of school: a review of intervention programs. J Sch Psychol. 2003; 41(5):377-95.

51. Berk, L. Infants, children, and adolescents. New York: Allyn and Bacon, 2005. 